\title{
SELECTION OF ISSR MOLECULAR PRIMERS FOR STUDIES OF GENETIC DIVERSITY IN Handroanthus impetiginosus (MART. EX DC.) MATTOS ${ }^{1}$
}

\author{
JÉSSICA MAIA ALVES PIMENTA ${ }^{2}$, FRANCIVAL CARDOSO FELIX ${ }^{3}$, JÉSSICA SABRINA OVÍDIO DE ARAÚJO², \\ CRISTIANE GOUVEAA FAJARDO ${ }^{2}$, MAURO VASCONCELOS PACHECO ${ }^{2 *}$
}

\begin{abstract}
Handroanthus impetiginosus is a tree species with ecological and economic potential. Despite that, in the Brazilian market, its wood is heavily exploited in the illegal trade. Therefore, studies on genetic diversity are necessary in order to propose strategies for conservation of this species. Thus, the aim of this study was to select Inter Simple Sequence Repeat (ISSR) primers for genetic diversity studies applied to the forest population of $H$. impetiginosus. For this, 30 ISSR molecular primers were tested in 30 individuals, evaluating the total number of loci, polymorphism rate and polymorphic information content, as well as marker index and resolving power. Eight primers were selected for having a better amplification pattern, which provided $62 \mathrm{loci}$. The polymorphic information content of the primers ranged from 0.34 to 0.49 , while the marker index (MI) averaged 3.20, with resolving power (RP) of 2.40, Nei's diversity (He) of 0.35 and Shannon index $(I)$ of 0.52 . The results show that the primers UBC 807, 809, 818, 824, 857, 860, 873 and 881 are efficient for quantifying the genetic diversity of $H$. impetiginosus. These results can contribute to supporting strategies aimed at the conservation of this species and selection of parent trees.
\end{abstract}

Keywords: Parent tree. Genetic conservation. Inter Simple Sequence Repeat. Semiarid.

\section{SELEÇÃO DE INICIADORES MOLECULARES ISSR PARA ESTUDOS DE DIVERSIDADE GENÉTICA EM Handroanthus impetiginosus (MART. EX DC.) MATTOS}

\begin{abstract}
RESUMO - Handroanthus impetiginosus é uma espécie arbórea com potencial ecológico e econômico. Apesar disso, no mercado brasileiro, a madeira é fortemente explorada no comércio ilegal. Portanto, tornam-se necessários estudos sobre diversidade genética com a finalidade de propor estratégias de conservação da espécie. Assim, o objetivo deste estudo foi selecionar iniciadores Inter Simple Sequence Repeat (ISSR) para estudos de diversidade genética aplicados a população florestal de $H$. impetiginosus. Para isso, testaram-se 30 iniciadores moleculares ISSR em 30 indivíduos, avaliando-se o número total de loci, taxa de polimorfismo e valor de conteúdo da informação polimórfica, bem como o índice de marcador e o poder de resolução. Oito iniciadores foram selecionados por apresentarem melhor padrão de amplificação, os quais forneceram 62 loci. $\mathrm{O}$ valor do conteúdo de informação dos iniciadores polimórficos variou de 0,34 a 0,49 , enquanto o valor do índice de marcador (MI) obteve uma média de 3,20, poder de resolução (RP) de 2,40, diversidade de Nei (He) de 0,35 e o índice de Shannon (I) de 0,52. Os resultados demonstram que os iniciadores UBC 807, 809, 818, $824,857,860,873$ e 881 são eficientes para a quantificação da diversidade genética de H. impetiginosus. Estes resultados podem contribuir para subsidiar estratégias que visem à conservação da espécie e seleção de árvores matrizes.
\end{abstract}

Palavras-chave: Árvore matriz. Conservação genética. Inter Simple Sequence Repeat. Semiárido.

\footnotetext{
${ }^{*}$ Corresponding author

${ }^{1}$ Received for publication in 10/15/2020; accepted in 08/10/2021.

Paper extracted from the master's dissertation of the first author.

${ }^{2}$ Specialized Academic Unit in Agrarian Sciences, Universidade Federal do Rio Grande do Norte, Macaíba, RN, Brazil; jessica.alves.pimenta@gmail.com - ORCID: 0000-0003-1009-7582, jessicaovidio@hotmail.com - ORCID: 0000-0002-9823-4379, genegoista00@gmail.com - ORCID: 0000-0001-6202-7143,pacheco.sementes@gmail.com - ORCID: 0000-0002-0447-9800.

${ }_{3}^{3}$ Department of Forest Sciences, Universidade Federal do Paraná, Curitiba, PR, Brazil; francival007@gmail.com - ORCID: 0000-00026518-5697.
} 


\section{INTRODUCTION}

Handroanthus impetiginosus (Mart. ex DC.) Mattos (Bignoniaceae) is a native tree species, whose wood is widely used due to its high density, durability, resistance against insects and fungi, which make it heavily exploited in Brazil (SILVA JUNIOR et al., 2017).

Illegal exploitation and the intense pressure of logging on this species stimulate efforts towards the conservation of existing populations (SILVA JUNIOR et al., 2017). These factors contribute strongly to the registration of $H$. impetiginosus in the Red Book of the Brazilian Flora (Livro Vermelho da Flora do Brasil) as a species of high economic value and decline of natural populations (verified or projected) (MARTINELLI; MORAES, 2013).

The advance of anthropic activities leads to fragmentation of natural areas, favoring the isolation of populations, which reduces genetic diversity and causes direct negative effects, such as changes in population dynamics and inbreeding (TELLES et al., 2014). Genetic variability directly affects the evolutionary dynamics of populations. Thus, the analysis of genetic diversity in forest populations provides information for the conservation and maintenance of species, contributing to the development of strategies for the conservation of genetic resources in situ or ex situ (FAJARDO; VIEIRA; MOLINA, 2014). Therefore, molecular primers are useful for the evaluation of genetic variability between populations and between individuals of the same population (VIEIRA et al., 2015).

Molecular primers are polymorphic DNA sequences, which can be analyzed at any stage of plant development and have the advantage of noninterference of the environment (VINSON et al., 2018). Among the molecular primers, the Inter
Simple Sequence Repeats (ISSR) have stood out as an efficient method for genetic characterization of populations, because they are effective in detecting DNA polymorphism and have low cost and high reproducibility (CHAGAS et al., 2015; VINSON et al., 2018).

Despite the continuous use of ISSR primers, there are few studies involving the methodology of selection and indication of the minimum number of loci for use in population genetics (VIEIRA et al., 2015). In this context, due to the need for more information for the conservation of $H$. impetiginosus to assist in future population conservation strategies and enable the analysis of the genetic structure of the population, the objective of this study was to select ISSR primers for genetic diversity studies applied to forest populations of $H$. impetiginosus.

\section{MATERIAL AND METHODS}

\section{Study site and sampling}

The collection of leaf samples for DNA extraction was carried out in the Açu National Forest (Floresta Nacional - FLONA) (5'34'20' $\mathrm{S}$ and $36^{\circ}$ 54' 33' W), Federal Conservation Unit (Ordinance No. 245 of $07 / 18 / 2001$ ), which is located in the municipality of Assu, Rio Grande do Norte state, Brazil. Thirty trees with minimum distance between individuals equivalent to twice their height (Figure $1)$, according to criteria described by Sebbenn (2002), were sampled. The data were registered in the National System of Management of Genetic Heritage and Associated Traditional Knowledge (Sistema Nacional de Gestão do Patrimônio Genético e do Conhecimento Tradicional Associado - SisGen) (registration number: A5DB85E).
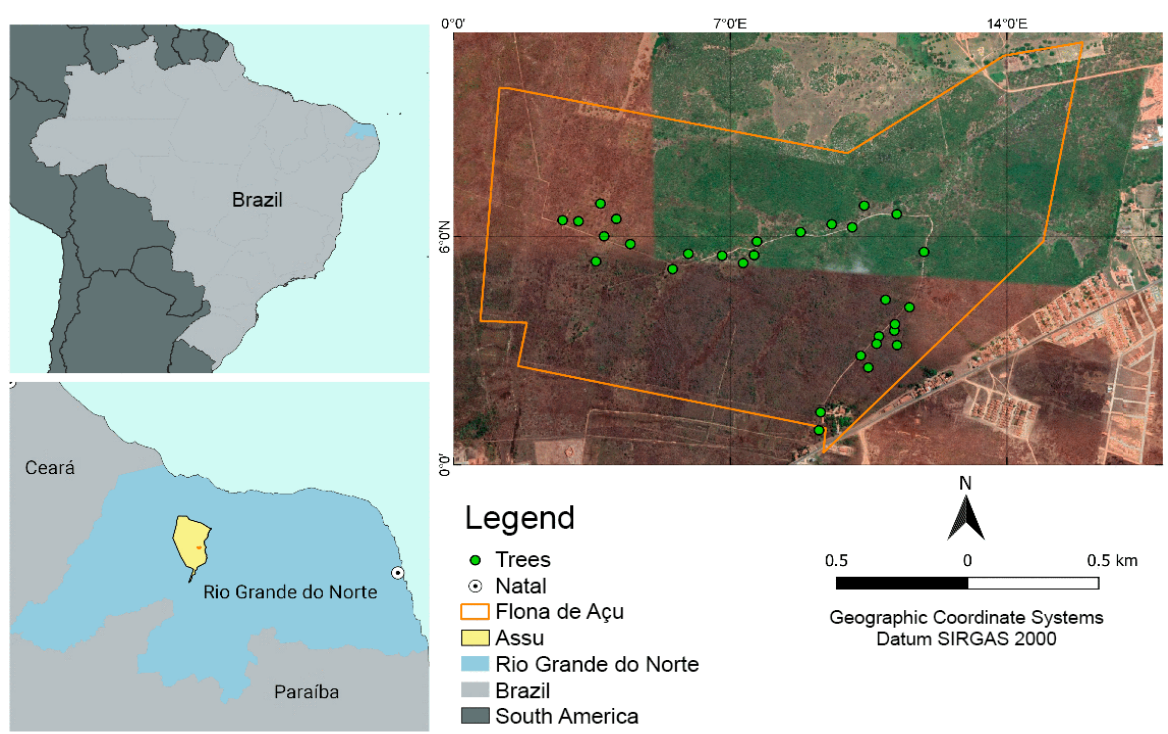

Figure 1. Geographical location of $H$. impetiginosus individuals sampled in the Açu National Forest. Geographic coordinate system. 
The leaf samples were placed in $2-\mathrm{mL}$ plastic tubes containing $2 \mathrm{X}$ cetyltrimethylammonium bromide (CTAB), identified and stored at $-20{ }^{\circ} \mathrm{C}$ until the moment of DNA extraction.

\section{DNA extraction, PCR and electrophoresis}

DNA was extracted by the CTAB method as proposed by Doyle and Doyle (1987), using $100 \mathrm{mM}$ of Tris $\mathrm{pH} 8.0,1.4 \mathrm{M}$ of NaCl, $20 \mathrm{mM}$ of EDTA $\mathrm{pH}$ $8.0,2 \%\left(\mathrm{w}^{-1} \mathrm{v}^{-1}\right)$ CTAB, $1 \%\left(\mathrm{w} . \mathrm{v}^{-1}\right)$ PVP-40 and $0.2 \%$ $\left(\mathrm{v} . \mathrm{v}^{-1}\right)$ of $\beta$-mercaptoethanol preheated to $60^{\circ} \mathrm{C}$ in a water bath. After extraction, the DNA obtained was quantified by spectrophotometer $\left(\operatorname{Epoch}^{\mathrm{TM}}\right)$.

Thirty ISSR molecular primers (UBC University of British Columbia) were tested using a sample composed of three individuals (bulk) randomly drawn from the population, followed by polymerase chain reactions (PCR). The primers selected for genetic analyses were those that showed the best amplification patterns and loci resolution quality.

PCR reaction amplification for $H$. impetiginosus individuals was performed with the combination of the following reagents: buffer (Buffer IC Phoneutria $\left.{ }^{\circledR}\right)(10 \mathrm{x})$, BSA $\left(1.0 \mathrm{mg} \cdot \mathrm{mL}^{-1}\right)$, $\mathrm{MgCl}_{2}(50 \mathrm{mM})$, dNTPs $(2.5 \mathrm{mM})$, primers $(2 \mu \mathrm{M})$, Taq polymerase $\left(0.5 \mathrm{U} \cdot \mu \mathrm{L}^{-1}\right)$, DNA $\left(50 \mathrm{ng} . \mu \mathrm{L}^{-1}\right)$ and ultrapure water.

DNA amplification reactions were performed in an automatic thermocycler (BioCycle ${ }^{\mathrm{TM}}$ ) during the period of $1 \mathrm{~h} 40 \mathrm{~min}$ according to the following steps: denaturation at $94{ }^{\circ} \mathrm{C}$ for $2 \mathrm{~min}$, followed by 37 cycles of $15 \mathrm{~s}$ at $94{ }^{\circ} \mathrm{C}$, annealing of primers at $47^{\circ} \mathrm{C}$ for $30 \mathrm{~s}$ and later for extension $1 \mathrm{~min}$ at $72{ }^{\circ} \mathrm{C}$. After the cycles, the process was finished by extension at $72{ }^{\circ} \mathrm{C}$, for $7 \mathrm{~min}$ and cooling at $4{ }^{\circ} \mathrm{C}$.

Then, PCR products were stained with bromophenol blue and GelRed ${ }^{\mathrm{TM}}$ solution and placed in a horizontal electrophoresis running tank containing agarose gel $\left(1.5 \mathrm{~m} \cdot \mathrm{v}^{-1}\right)$ at low luminosity. In this step, a control sample of PCR reaction and another sample with standard molecular weight of $1 \mathrm{~KB}$ (Ladder Kasvi ${ }^{\circledR}$ ) were placed. Subsequently, the agarose gel was immersed in a TAE $1 \mathrm{X}$ buffer solution (Tris-acetate-EDTA) and kept under a $100 \mathrm{~V}$ current for $2 \mathrm{~h}$ and $40 \mathrm{~min}$. After electrophoresis, the gels were photographed under ultraviolet light source with the device Ebox VX2 Vilbert Lourmat ${ }^{\mathrm{TM}}$.

With the results of amplification of the bands, a binary matrix was generated based on the presence (1) and absence (0) of the loci.

\section{Data analysis}

The parameters of genetic diversity were analyzed using the program POPGENE (Population Genetic Analysis) version 1.32 (YEH et al., 1997), where the percentage of polymorphic loci $\left(\% \mathrm{P}_{L}\right)$, Nei's genetic diversity $(\mathrm{He})$ and Shannon Index $(I)$ were obtained for the population.

Polymorphic information content (PIC) was used to evaluate the efficiency of the primers and to identify the polymorphism among individuals based on the absence or presence of bands. PIC was estimated according to the equation proposed by Anderson et al. (1993):

$$
\mathrm{PIC} i=1-\sum_{J=1}^{n} P^{2} i j
$$

Where $\mathrm{P}_{i j}$ is the frequency of the allele " $j$ " in the primer " $P$ ".

The results obtained in the calculation were classified into three categories, according to Botstein et al. (1980). Marker index (MI) (VARSHNEY et al., 2007), and resolving power (RP) were also calculated (PREVOST; WILKINSON, 1999).

In order to verify the optimal amount of polymorphic fragments for the genetic studies of a population of $H$. impetiginosus, bootstrap analysis was performed using GENES software (CRUZ, 2001). Amplified loci data were then used to estimate Nei's (1978) genetic distance, which was correlated with the genetic distance values simulated based on resampling of 10,000 permutations. The fit between genetic distances was verified by Kruskal stress, which indicates the fit between the original matrix and the simulated matrix.

Nei's (1978) genetic identity dendrogram was performed by the grouping method UPGMA (Unweighted Pair Group Method with Arithmetic Mean), using the program NTSYS v.2.11. (ROHLF, 1993).

\section{RESULTS AND DISCUSSION}

Among the 30 primers tested for $H$. impetiginosus, eight ISSR primers (UBC 807, 809, $818,824,857,860,873$ and 881) showed satisfactory amplification patterns and loci resolution quality according to previously established criteria. Only three primers (UBC 843, 851 and 859) did not have loci, not being indicated for studies of genetic diversity of this species.

The set of selected primers generated a total of 62 loci, ranging from 4 (UBC 860 and 881) to 16 (UBC 824), with an average of 8 per primer (Table $1)$. The primer UBC 857 had intermediate values of PIC (0.45) and resolving power (4.0), although it did not have a high number of alleles. These indices are important for detecting and choosing the best molecular markers. The primer was also efficient for studies of genetic diversity in other forest species, such as Elaeis guineensis Jacq. and Copernicia 
prunifera (Mill.) H.E. Moore, because in both studies UBC 857 had 14 loci and was classified as one of the best performing primers, demonstrating efficiency in the detection of bands in different species (CHAGAS et al., 2015; VIEIRA et al., 2015).

Table 1. Total number of loci, number of polymorphic loci $\left(\mathrm{P}_{L}\right)$, polymorphism rate $\left(\% \mathrm{P}_{L}\right)$, polymorphic information content (PIC), marker index (MI) and resolving power (RP) for eight ISSR primers tested in 30 individuals of $H$ impetiginosus.

\begin{tabular}{cccccccc}
\hline ISSR Primer & $\begin{array}{c}\text { Sequence of nucleotides } \\
\left(5,-3{ }^{\prime}\right)\end{array}$ & Loci & $\mathrm{P}_{\mathrm{L}}$ & $\% \mathrm{P}_{\mathrm{L}}$ & PIC & MI & RP \\
\hline UBC 807 & $(\mathrm{AG}) 8-\mathrm{T}$ & 9 & 9 & 100 & 0.45 & 4.05 & 2.60 \\
UBC 809 & $(\mathrm{AG}) 8-\mathrm{G}$ & 7 & 7 & 100 & 0.49 & 3.43 & 2.93 \\
UBC 818 & $(\mathrm{CA}) 8-\mathrm{G}$ & 8 & 8 & 100 & 0.47 & 3.76 & 2.87 \\
UBC 824 & $(\mathrm{TC}) 8-\mathrm{G}$ & 16 & 16 & 100 & 0.35 & 5.60 & 2.0 \\
UBC 857 & $(\mathrm{AC}) 8-\mathrm{YG}$ & 6 & 6 & 100 & 0.45 & 2.70 & 4.0 \\
UBC 860 & $(\mathrm{TG}) 8-\mathrm{RA}$ & 4 & 4 & 100 & 0.48 & 1.92 & 2.23 \\
UBC 873 & $(\mathrm{GACA})_{4}$ & 8 & 8 & 100 & 0.39 & 3.12 & 1.80 \\
UBC 881 & $(\mathrm{GGGTG})_{3}$ & 4 & 3 & 75 & 0.34 & 1.02 & 0.60 \\
\hline Average & & 8 & 8 & 97 & 0.43 & 3.20 & 2.40 \\
Total & & 62 & 61 & - & - & - & - \\
\hline
\end{tabular}

$\mathrm{R}=$ purines $(\mathrm{A}$ or $\mathrm{G})$ and $\mathrm{Y}=$ pyrimidines $(\mathrm{C}$ or $\mathrm{T})$. Nucleotide sequence.

The eight selected ISSR primers provided 61 polymorphic loci, that is, $97 \%$ of the total amplified loci (Table 1). The ability to detect polymorphism was high, as $88 \%$ of the primers obtained $100 \%$ polymorphism, which demonstrates that ISSR primers are effective in identifying genetic diversity in the analyzed population of $H$. impetiginosus. This polymorphism rate is high compared to values obtained with other sets of ISSR primers, used in Hancornia speciosa Gomes (47.62\%) (COSTA et al., 2015), Mimosa caesalpiniaefolia Benth. (52.7\%) (ARAÚJO et al., 2016; ARAÚJO et al., 2020), Plathymenia reticulata Benth. (65.88\%) (SOUZA et al., 2018) and Pityrocarpa moniliformis (Benth.) Luckow \& R. W. Jobson (82\%) (FELIX et al., 2020). However, when compared to a species of the same family (Bignoniaceae), the same result was obtained for Oroxylum indicum (L.) Vent. $\quad(88 \%$ polymorphism), a native and threatened species in India (RAJASEKHARAN et al., 2017).

The aim of PIC is to demonstrate the efficiency of molecular markers in relation to the detection of polymorphism among individuals, and the values ranged from 0.34 (UBC 824) to 0.49 (UBC 809), with an average of 0.43 (Table 1). According to Botstein et al. (1980), primers with PIC greater than 0.5 are classified as satisfactory in polymorphic information content, values from 0.25 to 0.5 are moderately informative, and values lower than 0.25 are poorly informative. Thus, the primers evaluated in the present study were considered moderately informative. ISSR primers with the same classification were considered efficient to estimate genetic diversity in studies with forest species in the Caatinga (COSTA et al., 2015; ARAÚJO et al., 2016; FELIX et al., 2021).

The marker index (MI) ranged from 1.02 (UBC 881) to 5.60 (UBC 824) with an average of 3.20. It was observed that the primers that generated the highest number of loci obtained higher values of MI (Table 1). Regarding the resolving power (RP) of the loci, a variation from 1.60 (UBC 881) to 8 (UBC 857 ) was observed, with an average of 4.81 . The MI and RP indices contribute to the detection of polymorphism and indicate the potential of each primer to distinguish individuals, helping in the choice of the most efficient primer for genetic diversity studies. Therefore, the higher the MI and RP parameters, the more indicated the use of the primer for the investigation of genotype variability (ROSA et al., 2017; RAVI; SIRIL; NAIR, 2020).

The sufficient number of loci for studies on genetic diversity in $H$. impetiginosus, according to bootstrap analysis, was 62 loci, because Pearson's correlation coefficient (r) and stress value (E) reached 0.99 and $0.02(\mathrm{p}<0.05)$, respectively. As the number of loci required for high precision estimates shows values lower than 0.05 for stress and close to 1.0 for correlation (KRUSKAL, 1964), it is assumed that the number of polymorphic loci generated by the set of primers (61 loci) can be considered sufficient for studies of genetic diversity 
in the target species of the present study (Figure 2). The definition of the minimum number of ISSR loci for the genetic diversity study through bootstrap analysis has contributed to optimizing the use of resources and time to characterize genetic diversity (ARAÚJO et al., 2016).

From the grouping of Nei's (1978) genetic identity, it is observed that there is an intermediate similarity between the individuals of $H$. impetiginosus, with formation of groups with 0.50 of genetic identity. The pairs of individuals with the highest values of genetic identity were 13 and 15 (0.87), 17 and 19 (0.85) and 5 and 10 (0.84), which were grouped into distinct clusters, suggesting that these individuals have greater genetic similarity to each other. In the dendrogram, from a cutoff point of 0.70 of Nei's (1978) genetic identity, it is possible to identify 10 groups: $\mathrm{G} 1(1,2,3,4,5,8$ and 10$)$; G2 (14 and 16); G3 (17, 19, 21, 23 and 24); G4 (28 and 29); G5 (20); G6 (25 and 27); G7 (26); G8 (6, 7, 9, $11,12,13$ and 15); G9 (18 and 22) and G10 (30) (Figure 3).

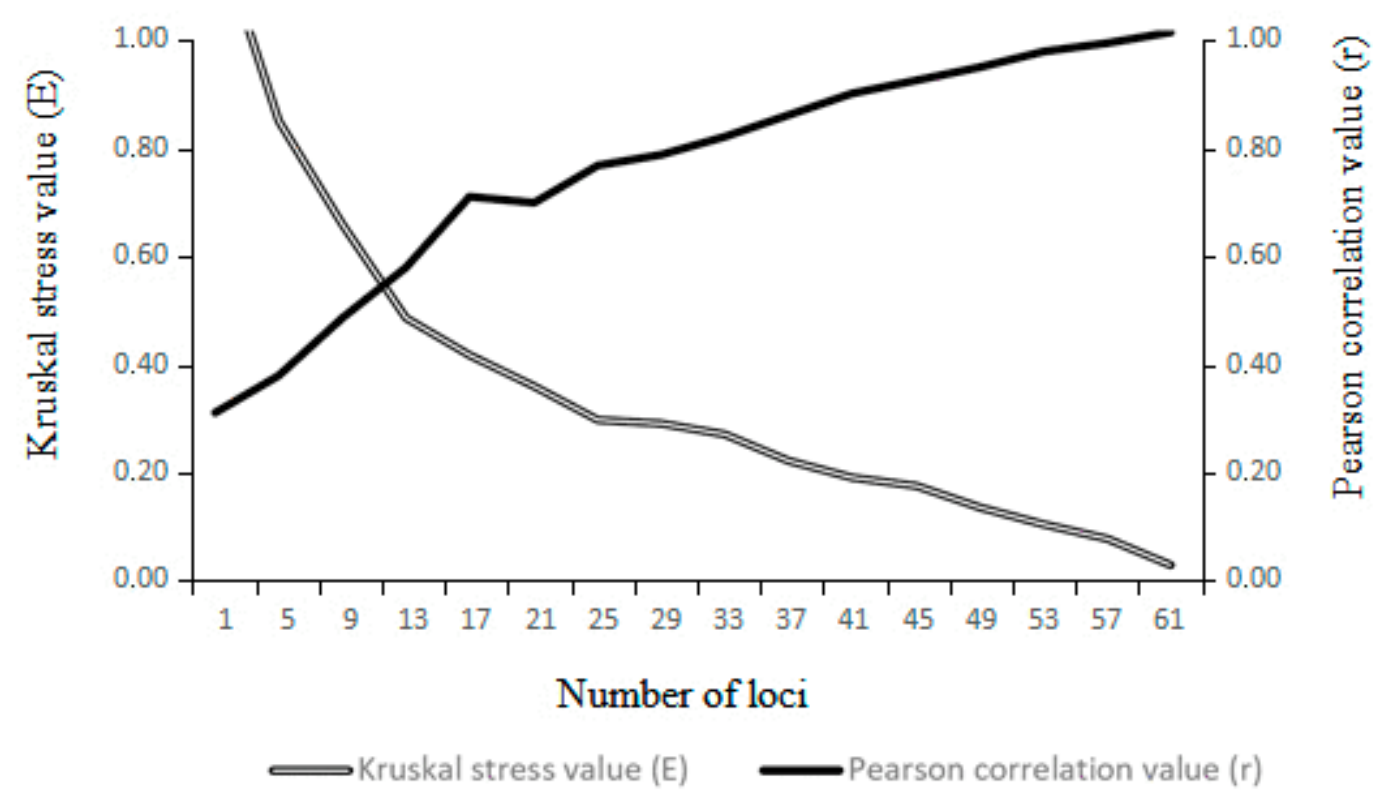

Figure 2. Values of Pearson's correlation (r) and Kruskal stress (E) as a function of the number of ISSR loci used to estimate the genetic diversity of 30 individuals of $H$. impetiginosus.

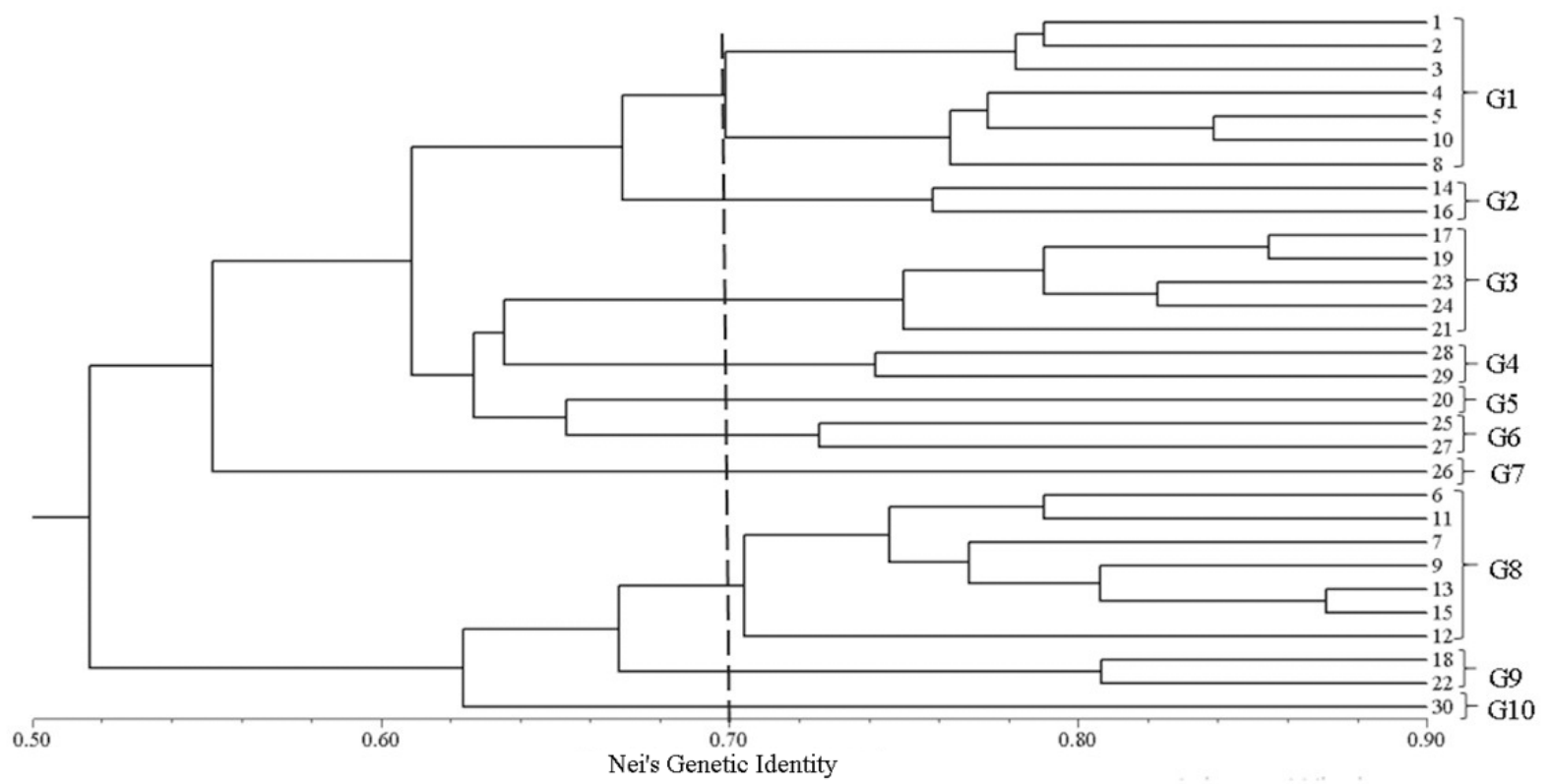

Figure 3. Dendrogram of Nei's genetic identity of 30 individuals of $H$. impetiginosus. 
The Nei's (1978) diversity index for the study population was $\mathrm{He}=0.35 \pm 0.15$, while the Shannon index (I) was $0.52 \pm 0.18$, which can be considered low to intermediate, when compared to the results obtained in studies with the same markers for other forest species (RAJASEKHARAN et al., 2017; FREIRE et al., 2019; LOPES; COSTA; ARRIEL, 2020).

The seed dispersal method, successional stages, geographic distribution and reproduction systems are some of the factors that can determine the levels and distribution of genetic variability between and within populations (NYBOM, 2004). $H$. impetiginosus is a perennial species, with anemochory dispersal and cross and selfincompatible fertilization (COLLEVATTI et al., 2014; SCHLINDWEIN et al., 2014). The value of He for $H$. impetiginosus $(0.52)$ was higher than expected for species with similar life parameters. According to Nybom (2004), the expected genetic diversity for long-life perennial species is 0.25 . Genetic diversity was also higher than expected for species with cross pollination (0.27), anemochory seed dispersal $(0.27)$ and climax successional stage (0.30) (NYBOM, 2004). The genetic variability found within the population may be associated with conservation status and absence of anthropic activity, as the area is a Conservation Unit.

The results obtained in this study are essential to support projects of conservation and restoration of natural populations of $H$. impetiginosus. In addition, the individuals analyzed showed potential to be used as parent plants for seed collection, because they had a high intrapopulation genetic diversity, based on the values of Nei's (1978) identity, Shannon index and through the UPGMA method.

Intrapopulation genetic characterization using ISSR molecular markers is useful for the selection of parent trees. The choice of individuals should be made based on the greatest genetic divergence, being a strategy to ensure the preservation of the species and the evolutionary dynamics of natural populations, besides fostering ecological restoration programs. It should be highlighted that this study was based only on one population of $H$. impetiginosus in the Caatinga biome, so it is necessary to conduct studies in other areas of natural occurrence, since the species has a wide geographical distribution.

\section{CONCLUSIONS}

The ISSR primers UBC 807, 809, 818, 824, $857,860,873$ and 881 detect sufficient genetic polymorphism among individuals for the analysis of $H$. impetiginosus genetic diversity.

The levels of genetic divergence in the $H$. impetiginosus population in the Açu National Forest (FLONA) demonstrate potential for the selection of parent trees and may contribute to supporting strategies aimed at the conservation of this species.

\section{ACKNOWLEDGMENTS}

The present study was carried out with support from the National Council for Scientific and Technological Development (CNPq) (Process 437955/2018-4) and the Coordination for the Improvement of Higher Education Personnel - Brazil (CAPES) - Funding Code 001. To ICMBio and to the manager of the Açu National Forest (FLONA), for the support provided during this project. To the Laboratory of Genetics and Forest Improvement (LABGen) of UFRN, for the infrastructure and support provided.

\section{REFERENCES}

ANDERSON, J. A. et al. Optimizing parental selection for genetic linkage maps. Genome, 36: 181 $-186,1993$.

ARAÚJO, F. et al. ISSR molecular markers for the study of the genetic diversity of Mimosa caesalpiniaefolia Benth. Idesia, 34: 47-52, 2016.

ARAÚJO, F. D. S. et al. Seed quality and genetic diversity of a cultivated population of Mimosa caesalpiniifolia Benth. Revista Caatinga, 33: 10001006, 2020.

BOTSTEIN, D. et al. Construction of genetic linkage map in man using restriction fragment length polymorphisms. American Journal of Human Genetics, 32: 314-331, 1980.

CHAGAS, K. P. T. et al. Seleção de marcadores ISSR e diversidade genética em uma população de Elaeis guineensis. Revista Brasileira de Ciências Agrárias, 10: 147-152, 2015.

COLLEVATTI, R. G. et al. High genetic diversity and contrasting fine-scale spatial genetic structure in four seasonally dry tropical forest tree species. Plant systematics and evolution, 300: 1671-1681, 2014.

COSTA, D. F. et al. Diversidade genética e seleção de iniciadores ISSR em uma população natural de mangaba (Hancornia speciosa Gomes) (Apocynaceae). Revista Brasileira de Fruticultura, 37: 970-976, 2015

CRUZ, C. D. Programa GENES: versão Windows. 
Viçosa, MG: Editora UFV, 2001. 642 p.

DOYLE, J. J.; DOYLE, J. L. Isolation of plant DNA from fresh tissue. Focus, 12: 13-15, 1987.

FAJARDO, C. G.; VIEIRA, F.; MOLINA, W. F. Interspecific genetic analysis of orchids in Brazil using molecular markers. Plant Systematics and Evolution, 300: 1826-1832, 2014.

FELIX, F. C. et al. Applications of ISSR markers in studies of genetic diversity of Pityrocarpa moniliformis. Revista Caatinga, 33: 1017-1024, 2020.

FELIX, F. C. et al. Selection of Pityrocarpa moniliformis (Benth.) Luckow \& R. W. Jobson mother trees for seeds production. Revista Brasileira de Ciências Agrárias, 16: 1-10, 2021.

FREIRE, A. D. S. M. et al. Genetic diversity in forest populations from conservation units in the Atlantic Rainforest in northeast Brazil. Revista Brasileira de Ciências Agrárias, 14:1-7, 2019.

KRUSKAL, J. B. Multidimensional scaling by optimizing goodness of fit to a no metric hypothesis. Psychometrika, 29: 01-27, 1964.

LOPES, J. D. S.; COSTA, M. R. J.; ARRIEL, D. A. A. Genetic diversity of potential mother trees of Myracrodruon urundeuva Allemão in a remnant population from Brazilian Cerrado using ISSR. Advances in Forestry Science, 7: 1017-1024, 2020.

MARTINELLI, G.; MORAES, M. A. Livro vermelho da flora do Brasil. Rio de Janeiro, RJ: Instituto de Pesquisas Jardim Botânico do Rio de Janeiro, 2013. 818 p.

NEI, M. Estimation of average heterozygosity and genetic distance from a small number of individuals. Genetics, 89: 584-590, 1978.

NYBOM, H. Comparison of different nuclear DNA markers for estimating intraspecific genetic diversity in plants. Molecular Ecology, 13: 1143-1155, 2004.

PREVOST, A.; WILKINSON, M. J. A new system of comparing PCR primers applied to ISSR fingerprinting of potato cultivars. Theoretical Applied Genetics, 98: 107- 112, 1999.

RAJASEKHARAN, P. E. et al. Genetic diversity in Oroxylum indicum (L.) Vent, a threatened medicinal plants from India by ISSR analysis. Indian Journal of Biotechnology, 16: 357-363, 2017.
RAVI, R. D.; SIRIL, E. A.; NAIR, B. R. The efficiency of Cytochrome P450 gene-based markers in accessing genetic variability of drumstick (Moringa oleifera Lam.) accessions. Molecular Biology Reports, 47: 2929-2939, 2020.

ROHLF, F. J. Numerical taxonomy and multivariate analysis system: version 1.8 . 1 . ed. Setauket, New York: Exeter Software, 1993. 43 p.

ROSA, J. et al. Variability and population genetic structure in Achyrocline flaccida (Weinm.) DC. a species with high value in folk medicine in South America. Plos one, 12: 1-19, 2017.

SEBBENN, A. M. Número de árvores matrizes e conceitos genéticos na coleta de sementes para reflorestamentos com espécies nativas. Revista do Instituto Florestal, 14: 115-132, 2002.

SCHLINDWEIN, C. et al. Visual signalling of nectar -offering flowers and specific morphological traits favour robust bee pollinators in the mass-flowering tree Handroanthus impetiginosus (Bignoniaceae). Botanical Journal of the Linnean Society, 176: 396-407, 2014.

SILVA JUNIOR, O. B. et al. Genome assembly of the Pink Ipê (Handroanthus impetiginosus, Bignoniaceae), a highly valued, ecologically keystone Neotropical timber forest tree. GigaScience, 7: 120-125, 2017.

SOUZA, L. C. et al. Validação do marcador molecular ISSR para detecção de diversidade genética em Plathymenia reticulata Benth. Revista Brasileira de Ciências Agrárias, 13: 1-6, 2018.

TELLES, M. P. C. et al. Disentangling landscape effects on population genetic structure of a Neotropical savanna tree. Brazilian Journal of Nature Conservation, 1: 65-70, 2014.

VARSHNEY, R. K. et al. Comparative assessment of ESTSSR, EST-SNP and AFLP markers for evaluation of genetic diversity and conservation of genetic resources using wild, cultivated and elite barleys. Plant Science, 173: 628-649, 2007.

VIEIRA, F. A. et al. Diversidade genética de Copernicia prunifera com o uso de marcadores moleculares ISSR. Revista Brasileira de Ciências Agrárias, 10: 525-531, 2015.

VINSON, C. C. et al. Using molecular markers to investigate genetic diversity, mating system and gene flow of Neotropical trees. Brazilian Journal of Botany, 41: 481-496, 2018. 
YEH, F. C. et al. Pop-gene, theuser-friendly shareware for population genetic analysis molecular biology and biotechnology center. Edmonton: Molecular Biology and Biotechnology, 1997. 